\title{
Ripe nectarines segregated through sensory quality evaluation and electronic nose assessment
}

\author{
Rodrigo INfante*, Pía Rubio, C. Meneses, L. Contador
}

Department of Plant Science, University of Chile, Av. Santa Rosa 11.315 Santiago, Chile, 8820808, rinfante@uchile.cl

${ }^{*}$ Correspondence and reprints

Fruits, 2011, vol. 66, p. 109-119 (C) 2011 Cirad/EDP Sciences All rights reserved DOI: $10.1051 /$ fruits/2011020 www.fruits-journal.org

RESUMEN ESPAÑOL, p. 119

\section{Ripe nectarines segregated through sensory quality evaluation and electronic nose assessment.}

Abstract - Introduction. The aim of this study was to determine the ability of an electronic nose (e-nose) to predict the quality of nectarines and peaches, and, in particular, the aroma. Materials and methods. Four nectarine cultivars ('María Dolce', 'Maillarlate', 'Nectaross' and 'Venus') and one peach cultivar ('Royal Glory') were evaluated. The fruit was harvested ripe and the quality evaluations were carried out just one day after harvest. The intensity of the main descriptors of fruit quality was described, and fruits were subjected to an e-nose assessment. The sensory analysis and the e-nose results were presented through a Principal Component Analysis (PCA). A multiple linear regression (MLR) was also used to create a predictive model for the attribute 'aroma' compared with the other sensory parameters and the most informative e-nose sensor data. Results and discussion. 'Royal Glory' and 'María Dolce' were placed in a separate cluster far from 'Venus', 'Nectaross' and 'Maillarlate'. The result of the MLR included the attributes 'acidity', 'sweetness' and 'acceptability' in the model, and the data registered by sensor 6 of the enose (SnO2-sensor, RGTO Mo, $45 \AA$ thick layer), which were those factors that best related to the aroma, reached a $R^{2}$ of 0.48 and a mean square error (MSE) of 3.85. It was concluded that the e-nose is an instrument able to discriminate peach varieties through their aromatic features, which are among the descriptors that mainly determine acceptability by the peach consumer.

Chile / Prunus persica / fruits / varieties / segregation / volatile compounds / olfaction / measuring instruments

\section{Ségrégation de nectarines mûres par évaluation de leur qualité sensorielle et utilisation d'un nez électronique.}

Résumé - Introduction. Le but de cette étude a été de déterminer l'aptitude d'un nez électronique (e-nez) à prédire la qualité de nectarines et de pêches, et, en particulier, l'arôme apte à être apprécié par un jury. Matériel et méthodes. Quatre cultivars de nectarines (María Dolce, Maillarlate, Nectaross et Venus) et un cultivar de pêche (Royal Glory) ont été évalués. Les fruits ont été récoltés à maturité et l'évaluation de la qualité a été réalisée juste un jour après la récolte. La gamme des principaux descripteurs de la qualité du fruit a été décrite, et les fruits ont été soumis à une évaluation par nez électronique. L'analyse sensorielle et les résultats obtenus par e-nez ont été soumis à une analyse en composantes principales (ACP). Une régression linéaire multiple (RLM) a également été utilisée pour créer un modèle prédictif pour le descripteur " arôme " à partir d'autres paramètres sensoriels et des données les plus informatives obtenues par capteur e-nez. Résultats et discussion. María Dolce et Royal Glory ont été placés dans un groupe éloigné de Maillarlate, Nectaross et Venus. Le résultat de la RLM a inclus les attributs " acidité ", " douceur ", " acceptabilité " dans le modèle, et les données enregistrées par le capteur 6 du e-nez (capteur SnO2, RGTO Mo, 45 Å d'épaisseur), qui ont été les facteurs les mieux liés à l'arôme, ont permis d'obtenir un coefficient $R^{2}$ de 0,48 et une erreur quadratique moyenne de 3,85. Il a été conclu que le nez électronique est un instrument apte à discriminer les variétés de pêchers à partir de leurs caractéristiques aromatiques, qui sont parmi les principaux descripteurs permettant de déterminer l'acceptabilité des pêches par le consommateur.

Chili / Prunus persica / fruits / variété / ségrégation / composé volatil / olfaction / instrument de mesure 


\section{Introduction}

In the peach industry, there are different agents that interact with fresh fruits, in their production, distribution and commercialization before the product reaches consumers. Each agent in this chain has different requirements and definitions of what quality means. The approach of the first links in this chain (production and distribution) is often oriented towards the features of the product, which are determined using analytic methods. This approach to fruit quality supplies objective data useful for carrying out market decisions. On the other hand, instrumental quality measurements are limited by the precision and ease of the technique employed; so the easiest parameters to appraise are also the most used in fruit quality control. The ground color, the flesh firmness, the soluble solids concentration and the titratable acidity are among the most used parameters compared, for example, for aroma determination [1]. However, are these parameters linked in some way with consumer appreciation? The approach based on the intrinsic quality of the product is the best way to follow the fruit's physiological changes throughout the market chain; but, it fails because it does not take human perceptions into account. Therefore, a more complete definition of fruit quality must consider both the instrumental and the sensory approaches. Sensory analysis techniques are of help in understanding the fruit's quality and its positive reception based on specific traits that can be studied to develop standard sensory evaluation protocols. Establishing the correlation between the sensory descriptors and the analytic parameters is the only way to be able to determine the satisfaction produced by fruit consumption as a measurable parameter.

Sensory techniques are tools to gain insight into consumer preferences, which, combined with the determination of physical and chemical parameters, provide a more detailed definition of fruit quality [2].

Aroma is one of the attributes that mainly determines the acceptance of a fruit [3] and it is associated with ripening [4]. Aroma is generated by the emission of volatiles from the skin and flesh of the fruit, which are detected when they enter the nasal cavity to the back of the throat and are perceived by the olfactory receptor system [5]. While sugars and acids contribute to sweetness and tartness, aroma is derived from combinations of volatile molecules. The different proportions of the volatile components and the presence or absence of trace components often determine aroma properties [6]. The fruit's aroma, and consequently its quality, could be improved by initiating the harvest when the fruit is ripe, at least until the physiological ripening is complete on the tree [7].

The electronic nose (e-nose) is one of the most promising non-destructive devices used in fruit quality assessment, and it is based on new chemical sensors that utilize differences in the electrochemical properties of volatiles $[2,8]$. The sensors come into contact with volatiles, which are adsorbed in a thin layer reaction, generating a resistance that is transformed into an electrical signal. Through the use of an algorithmic model that processes the resistance data from each sensor, the volatile compound's data are expressed as a whole via a multivariate analysis. The e-nose has had several applications in food research, such as determining the most appropriate harvest maturity in fruits [9, 10], establishing quality indexes [11], or predicting the sensory quality associated with different harvest dates [12].

The objective of our research was to test the ability of the e-nose to discriminate ripe peaches, and to compare the observed segregation pattern given by the e-nose with the result obtained by sensory analysis through a trained panel. An additional aim was to define the relation that exists between the principal chemical and sensory parameters with the perception of the aroma using a multiple linear regression.

\section{Materials and methods}

The yellow-fleshed nectarine cultivars 'Venus', 'María Dolce', 'Nectaross' and 'Maillarlate' and the yellow-fleshed peach 'Royal Glory' were used in this study. Fruits were 
harvested when the ground color was yellow, from an arboretum in Paine, near Santiago, Chile. Then, in the lab, the fruits were sorted non-destructively using a Durofel portable device (Agrotecnologies, Tarascon, France). A sample of homogeneous fruits was used to characterize the initial ripeness level through the flesh firmness, the soluble solids concentration (SSC), the titratable acidity (TA), the ground color and the fruit weight. The day after harvest, fruits were submitted to sensory analysis and e-nose evaluation.

\subsection{Quality indexes}

The flesh firmness was measured on both cheeks and both shoulders of each fruit, using a portable penetrometer (Effegi, Milan, Italy) with a 7.9-mm probe. The SSC was measured with a thermo-balanced PAL-1 refractometer (Atago, Tokyo, Japan) and the TA was assessed in $10 \mathrm{~mL}$ of juice, buffered with $\mathrm{NaOH} \quad 0.1 \mathrm{~N}$, and then expressed as $\%(\mathrm{p} / \mathrm{v})$ of malic acid. The fruit weight was individually determined using an electronic balance (Tech Master, California, USA). The ground color was measured with a CR-300 colorimeter (Minolta, Tokyo, Japan). The lightness $(L)$, the saturation $(C)$ and hue angle $(H)$ were used to characterize changes in skin color from green to yellow during the ripening progress [13]. Twentyfour fruits per cultivar were used for maturity characterization.

\subsection{Sensory analysis}

The sensory analysis was performed at individual conventional booths by a trained panel of twelve individuals (aged 25-55). The training period of the panel in fresh fruit evaluation, for a total of $12 \mathrm{~h}$, was carried out during the same harvest season. Six sessions were undertaken to discuss and standardize the criteria and definition of quality parameters. The fruit samples that were presented to each assessor were evaluated at the same flesh firmness range (60-70 Durofel Units). The samples were prepared in a white pottery dish by presenting a slice of fruit with its skin, cut and prepared less than 5 min before testing them, to ensure a glossy appearance and avoid the enzymatic browning of the flesh. The dish containing the sample was identified by a 3-digit code randomly assigned corresponding to the same code presented in a separate evaluation guideline. The evaluation guideline used a continuous scale for each attribute, ranging from 0 to 15 , marked with two anchors, $0=$ the lowest level for that specific attribute and $15=$ the highest level for that specific attribute, previously used in stone fruit quality evaluation [10]. The attributes evaluated were aroma, sweetness, acidity, juiciness, texture, flavor and acceptability.

\subsection{E-nose analysis}

The analytical system used to determine the total volatiles produced by the fruits was an Electronic Olfactory System (EOS835) (Sacmi, Imola, Italy) composed of six metal oxide sensors, and a personal computer used for the acquisition and processing of the data generated. The device was connected to the malaxer by a steel feeler for headspace transfer from the malaxer chamber to the metal oxide semiconductor (MOS) array chamber, and it was equipped with two valves for the air inlet (air valve) and the headspace to analyze the gas (gas valve) [14]. Each individual fruit was placed in an airtight glass with a volume of $1,500 \mathrm{~mL}$ once the headspace had been homogenized for $10 \mathrm{~min}$ at $22^{\circ} \mathrm{C}$. The duration of each measurement was programed by the EOS835 software before the malaxation process began. Each measurement consisted of four steps: "before" (30 s) = the period before real analysis: at this time, there were no data registered; "during" (180 s) = the air valve was closed, whereas the gas valve was opened; the malaxer headspace was transferred to the MOS array, and the data were collected by each sensor during this step; "after" (30 s) = the gas valve was switched and the air valve was opened to restore the original MOS conditions; "wait" (180 s) and "cleaning" (100 s) = the transition time before a new measurement began.

With the exception of the "during" step, the gas valve was maintained in a switched position and only carrier air was blown into 
the sensor chamber; this caused the sensor signal to return to the baseline. Pure synthetic air was used as a reference gas during the recovery phase of the measurement cycle. The previous conditions ensured that the baseline reading had indeed been recovered before performing the next analysis. The same flow $\left(150 \mathrm{~mL} \cdot \mathrm{s}^{-1}\right)$, same chamber temperature $\left(22^{\circ} \mathrm{C}\right)$ and same relative humidity (80\%) were used for each determination.

The sensor response extracted by each sensor consisted of the sequence expression $X=\left[\mathrm{R} / \mathrm{R}_{0}\right]$, where $\mathrm{R}_{0}$ was the initial resistance of the sensor balanced in the air, $\mathrm{R}$ was the resistance of the sensor in the presence of the volatile compounds emitted from the fruits (which decreased with respect to $\mathrm{R}_{0}$ ), and $X$ was the response of each sensor recorded, expressed in Ohms [14].

\subsection{Statistical analysis}

Fruit maturity characterization was performed in a completely random design with analysis of variance (ANOVA) [15]. Treatments were set for each cultivar, and 24 replications were used for the fruit weight, the SSC, the flesh firmness (penetrometer and Durofel) and the ground color. The TA data was the mean of six samples. Following the ANOVA, significant differences between means were determined by the Tukey separation test $(p \leq 0.05)$.

For the data registered with the e-nose, a PCA was performed using the Nose Pattern Editor program (SACMI, Imola, Italy). The sensory evaluation data underwent a principal component analysis [15]. The data were placed on a two-dimensional plot, and a Pearson's correlation among variables was performed. In both cases, 12 replications of a single fruit each per cultivar were used.

A multiple linear regression (MLR) was performed step-by-step in order to establish a prediction model. The data were separated into two groups: the first group was for developing the model (40 fruits in total, eight per each variety) and the other group was for prediction (20 fruits, four per variety). MLR is a common method used in quantitative analysis for studying the func- tional relationship between a response " $Y$ " (dependent variable) and a variable " $X$ " (independent variable). The regression is studied as changes in the $X$ variables affect the response by fitting a model for the functional relationship between the two parameters [16]. The equation of the multiple linear regression model is: $Y_{i}=\beta_{0}+\beta_{1} x_{1 i}+\beta_{2}$ $x_{2 \mathrm{i}}+\ldots+\beta_{\mathrm{k}} x_{k i}+\varepsilon_{\mathrm{i}}$, where $Y_{i}$ is the $i$ th observation of the dependent variable $Y ; x_{1 i}, x_{2 i}$, ....., $x_{k i}$ are the ith values of the independent variables $x_{1}, x_{2}, \ldots, x_{k} ; \beta_{0}$ is the unknown parameter that represents the ordered origin of linear function; $\beta_{1}, \ldots, \beta_{k}$ are the unknown parameters representing the rates of change in $Y$ compared with the unit change of $x_{1}$, $x_{2}, \ldots, x_{k}$, respectively, and $\varepsilon_{\mathrm{i}}$ is the random error term.

The use of a linear regression allows one to choose the subset of regressor variables that should be in the model. This procedure is part of the regression model with all the regressor variables, and each stage was subsequently raised as if all input variables should be maintained. The algorithm ends when no variable enters or leaves the model [17]. This work was used as a threshold to enter or leave the model at a $p$-value of 0.15 .

Consequently, to find the best value among the values returned by each sensor and quality attributes, verification of the calibration model through the mean square error (MSE) was used, while the coefficient of determination $\left(R^{2}\right)$ was used to verify the proposed model for the relationship between the predicted and the observed values. A valid model should have low MSE and high $R^{2}$ values. In addition, the validation was performed through normality and homogeneity tests [16].

\section{Results and discussion}

\subsection{Quality indexes}

Intrinsic peach quality can be investigated through several physical and chemical parameters. Most studies focus on a limited number of parameters, and identifying those of major importance for quality would be highly beneficial. The main parameters 
Table I.

Maturity parameters determined on "tree-ripe" nectarine and peach cultivars harvested in central Chile (mean values of $n=24$ fruits).

\begin{tabular}{|c|c|c|c|c|c|c|c|c|c|c|}
\hline \multirow[t]{2}{*}{ Variety } & \multirow{2}{*}{$\begin{array}{l}\text { Harvest } \\
\text { date }\end{array}$} & \multirow{2}{*}{$\begin{array}{l}\text { Weight } \\
\text { (g) }\end{array}$} & \multirow{2}{*}{$\begin{array}{c}\text { Soluble solids } \\
\text { concentration (SSC) } \\
(\%)\end{array}$} & \multirow{2}{*}{$\begin{array}{l}\text { Flesh } \\
\text { firmness } \\
(\mathrm{N})\end{array}$} & \multirow{2}{*}{$\begin{array}{l}\text { Flesh firmness } \\
\text { (Durofel units) }\end{array}$} & \multirow{2}{*}{$\begin{array}{l}\text { Titratable } \\
\text { acidity (TA) } \\
\text { (\%) }\end{array}$} & \multirow{2}{*}{$\begin{array}{c}{[\mathrm{SSC} / \mathrm{TA}]} \\
\text { ratio }\end{array}$} & \multicolumn{3}{|c|}{ Ground color } \\
\hline & & & & & & & & Lightness & Chroma & Hue \\
\hline María Dolce & Feb. 3rd & $248.3 b$ & $14.7 \mathrm{c}$ & $15.68 \mathrm{a}$ & $59.9 \mathrm{a}$ & $0.4 \mathrm{c}$ & $39.7 \mathrm{c}$ & $72.4 \mathrm{~b}$ & $53.7 \mathrm{~b}$ & $49.1 \mathrm{a}$ \\
\hline Nectaross & Jan. 26th & $214.3 \mathrm{a}$ & $12.8 \mathrm{~b}$ & $23.52 b$ & $74.5 \mathrm{~b}$ & $1.1 \mathrm{e}$ & $11.6 \mathrm{a}$ & $74.9 \mathrm{~b}$ & $53.6 \mathrm{~b}$ & $54.0 \mathrm{a}$ \\
\hline Maillarlate & Jan. 26th & $268.4 \mathrm{~b}$ & $18.5 \mathrm{~d}$ & $21.56 \mathrm{ab}$ & $65.8 a b$ & $0.3 \mathrm{~b}$ & $63.9 \mathrm{e}$ & $70.5 \mathrm{~b}$ & $51.5 \mathrm{~b}$ & $62.0 \mathrm{~b}$ \\
\hline Royal Glory & Dec. 28th & $254.3 \mathrm{~b}$ & $11.4 \mathrm{a}$ & $18.62 a b$ & $64.3 \mathrm{ab}$ & $0.2 \mathrm{a}$ & $53.3 \mathrm{~d}$ & $49.9 \mathrm{a}$ & $32.9 \mathrm{a}$ & $62.7 \mathrm{~b}$ \\
\hline Venus & Jan 19th & $300.4 \mathrm{c}$ & $14.3 \mathrm{c}$ & $18.62 a b$ & $66.9 \mathrm{ab}$ & $1.0 \mathrm{~d}$ & $14.0 \mathrm{~b}$ & $72.5 \mathrm{~b}$ & $53.6 \mathrm{~b}$ & $60.2 \mathrm{~b}$ \\
\hline
\end{tabular}

Different letters in the same column indicate significant differences $(p \leq 0.05)$.

that define the ripeness level, and which are commonly used in stone fruits, are ground skin color, soluble solids concentration (SSC), flesh firmness and titratable acidity (TA) [2]. A generic single quality index based on SSC has also been developed [18-20].

The SSC of the nectarines 'María Dolce' and 'Venus' showed no difference, but the SSC of 'Nectaross', 'Maillarlate' and 'Royal Glory' did present differences within the group (table I). 'Maillarlate' showed the highest SSC (18.5\%); by contrast, 'Royal Glory' showed the lowest SSC. Final concentrations of fruit biochemicals at maturity result from changes during fruit development. Sucrose, glucose and fructose are the main sugars in peach fruits, followed by sorbitol, a sugar alcohol, in smaller amounts [21, 22].

Flesh firmness is a basic indicator of peach quality, which is related to horticultural maturity at harvest and must be maintained from harvest to consumption. However, the firmness measurement should be supported by other approaches coupling sensory and instrumental measurements to appreciate desirable quality traits better, such as crispness and crunchiness [23].

All the cultivars showed flesh firmness between $15 \mathrm{~N}$ and $24 \mathrm{~N}$, a flesh firmness range that characterizes the peaches as "ready to eat", which is associated with the maximum reachable quality of a fruit [24]. Nevertheless, 'María Dolce' and 'Nectaross' showed significant differences, with the latter reaching the highest flesh firmness. This trait is one of the most important parameters of peach quality and is a principal attribute considered by peach consumers [25].

The TA showed differences among all the varieties; 'Nectaross' showed the highest value and 'Royal Glory' the lowest (table I). 'María Dolce' is classified as a sub-acid fleshed cultivar [26], and these genotypes are characterized by a TA in the range of $0.3-$ $0.5 \%$ [27], coinciding with the observed TA values. However, 'Royal Glory' and 'Maillarlate', both varieties classified as normal acid genotypes, also showed a TA even lower than that observed in 'María Dolce'. This behavior could surely be explained by the low TA of sub-acid genotypes being particularly evident in fruits with higher flesh firmness or less ripe ones. The TA of "tree-ripe" fruits decreases the product of the oxidation of the organic acids [27] that takes place during the final phases of ripening, and the differentiation between normal and sub-acid cultivars is only possible before these ripening phases are completed. The [SSC / TA] ratio was different among all the varieties. 'Maillarlate' showed the highest ratio, a product of its low TA and high SSC. This ratio is quite relevant because it determines sweetness. In fact, sweetness perception is known to be affected by a number of parameters, in particular acidity, with the overall consumer appreciation related more to the [TA / SSC] index ratio than to the SSC alone [28]. 
Fruit pigments are the chemicals responsible for skin and flesh color, and, during the ripening period, many fruits undergo significant changes in their pigment composition. These changes include both the degradation of existing pigments and the synthesis of new pigments, and, in many cases, both processes occur simultaneously. Among these pigmentation changes, chlorophyll degradation is of paramount importance in many products as it is used as a primary criterion for assessing ripening stage and quality [29]. The ground color lightness $(L)$ and the saturation $\left(C^{*}\right)$ did not show any differences in 'María Dolce', 'Nectaross', 'Maillarlate' and 'Venus', but statistical differences were observed between them and 'Royal Glory' (table I). The ground color hue $\left(b^{\circ}\right)$ did not show any differences among 'Royal Glory', 'Maillarlate' and 'Venus', but statistical differences were observed between 'María Dolce' and 'Nectaross'.

\subsection{E-Nose}

The e-nose permitted cultivars to be grouped and differentiated based on the composition and concentration differences of volatiles, results which have been corroborated by other studies on peaches [10, 29, 30] and apples [31]. The compositions of volatiles and their intensity correspond to an intrinsic characteristic of each variety [32] and its ripening stage [10].

In addition, Moltò et al. [33] employed gas chromatography to investigate the main chemical components of peach aroma and related their concentration to the response of transducers sensitive to delta and gamma decalactones. Sensor responses had good correlations with a classification made by experts based on visual appearance of ripening. The sensors were more sensitive, also detecting skin breakage, and showed a good correlation with firmness measurements determined with a penetrometer. The e-nose has been tested for evaluating sensorial properties of peaches and nectarines, obtaining results that encourage further investigations into interactions between natural olfaction and the e-nose [4]. Since visual aspect and aroma are primary aspects of peach quality, Di Natale et al. [34] combined visible spectra and e-nose data as an improvement of overall fruit quality in a non-destructive determination. In another study, this instrument was able to discriminate four peach cultivars even if they shared a common progenitor, indicating the power of the instrument for genetic studies [35].

In assessing the response of each sensor, it was found that S6 (SnO2, RGTO Mo, $45 \AA$ ) showed the most consistent and significant results in terms of ability to segregate varieties, and it was therefore selected for building up the PCA and the predictive model. A subset of a few sensors can thus be chosen to explain the behavior of volatile compounds. This result agrees with that obtained by Hernández Gómez et al. [36], where only three sensors in a total of 10 had a greater influence in the current pattern file for mandarins.

According to the PC1 (89.32\%), 'Nectaross', 'Maillarlate' and 'Venus' were grouped far from cultivars 'Royal Glory' and 'María Dolce', being settled on different quadrants of PC1 (figure 1). This separation demonstrates the ability of the e-nose to segregate varieties depending on the composition of their volatiles. Similar results have been achieved in other studies on apricots [37, 38].

By contrast, an e-nose employed to establish quality index models able to describe the different picking dates of 'Xueqing' pear found that flesh firmness and SSC exhibited a good prediction performance; however, for TA, there was a very poor correlation with the signal of the e-nose [12].

The results given by the e-nose could not show us which or at what concentration volatile compounds were present, but it did allow segregation between varieties or stages of maturity considering the overall aroma. This provides a quick system to classify and differentiate food without the need to determine the chemical composition of the gas phase [39].

\subsection{Sensorial analysis}

Fruit quality is associated with different attributes that vary during ripening, producing changes in sensorial traits and consumer acceptance. Sensory evaluation in stone 


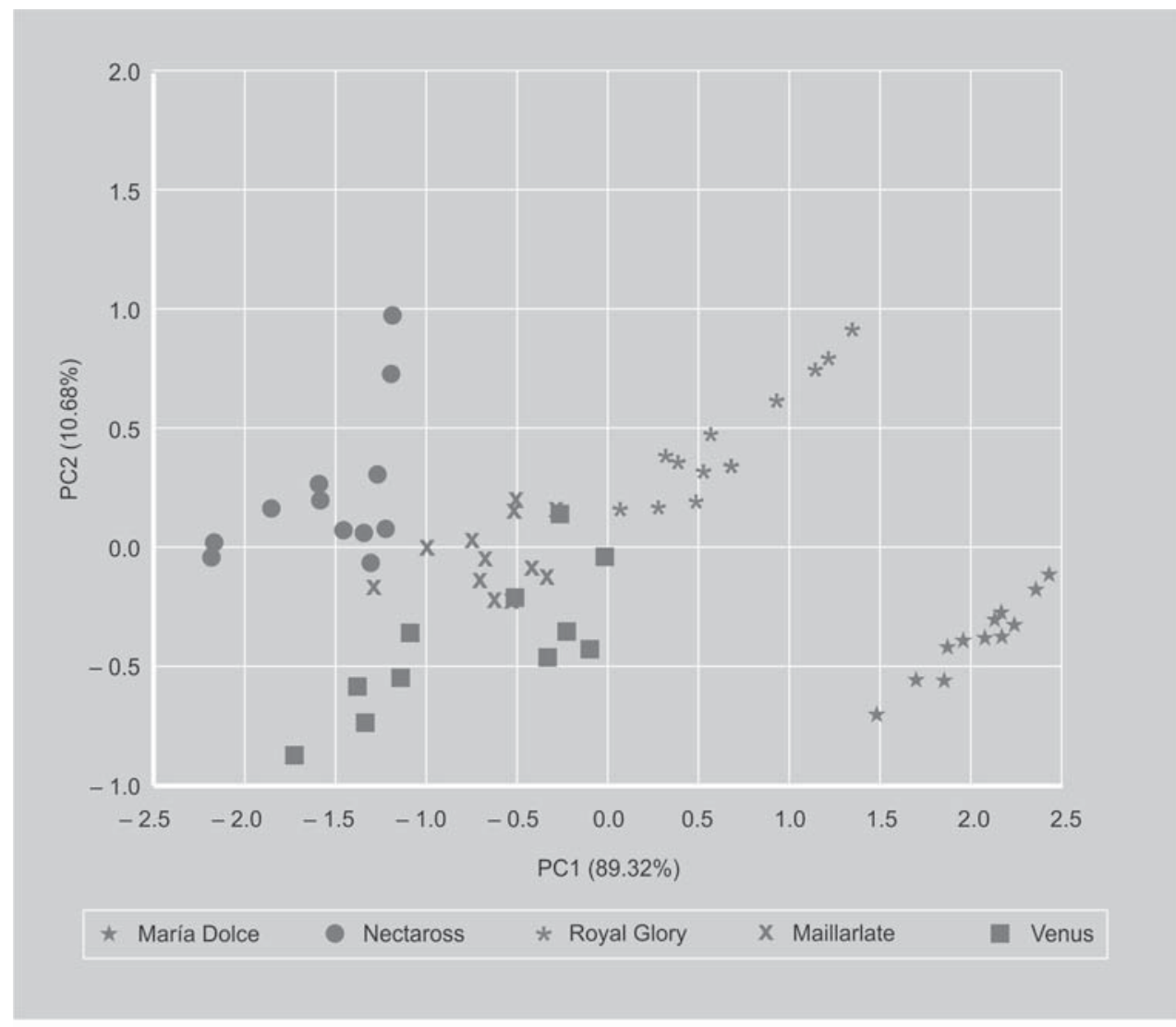

Figure 1.

Principal component analysis determined with the electronic nose system EOS835

(sensors 1 and 6), at harvest on "tree-ripe" nectarine and peach cultivars harvested in central Chile.

fruits should consider the climacteric phase of the ripening process, and standardized flesh firmness, around 1-2 kg [10]. The strength of sensory evaluation is the possibility of providing a complete fruit profile, valid for product comparisons, shelf-life monitoring and prediction of consumer acceptance. This allows for weighting single parameters in terms of influence on overall perception [2].

In the sensorial analysis conducted through the trained panel, the PCA explained $90.6 \%$ of the total variation of the model, with $65 \%$ on the PC1 and $25.6 \%$ on the PC2 (figure 2). The variable couples showing positive correlation were 'sweetness'-'juiciness', 'sweetness'-'texture', 'juiciness'-'texture' and 'texture'-'flavor'. 'Aroma' appeared independent of 'juiciness' and 'sweetness' (table II). The 'acceptability', 'flavor' and 'texture' showed a high correlation with PC1, while 'aroma', 'acidity' and 'sweetness' behavior explained PC2 (figure 3). In this case, it was observed that the conformation of one cluster containing 'Nectaross', 'Maillarlate' and 'Venus' was best associated with 'flavor', 'sweetness', 'juiciness', 'acceptability' and 'texture'. The cultivar 'Royal Glory' appeared alone, showing no association with any sensory attribute, and a somewhat analogous situation was observed with 'María Dolce' (figure 2). This sorting pattern of the genotypes generated by the trained panel evaluation was also observed with the analysis carried out by means of the e-nose.

Similarly, Crisosto et al. [20] segregated cultivars of 23 peaches and 26 nectarines according to the sensory perception of their organoleptic characteristics through a trained panel, generating a minimum quality index for each organoleptic group rather than proposing a generic minimum quality index based on SSC. Brovelli et al. [40] emphasize the usefulness of descriptive sensory evaluation and principal component analysis in evaluating the sensory quality of new cultivars. 


\section{R. Infante et al.}

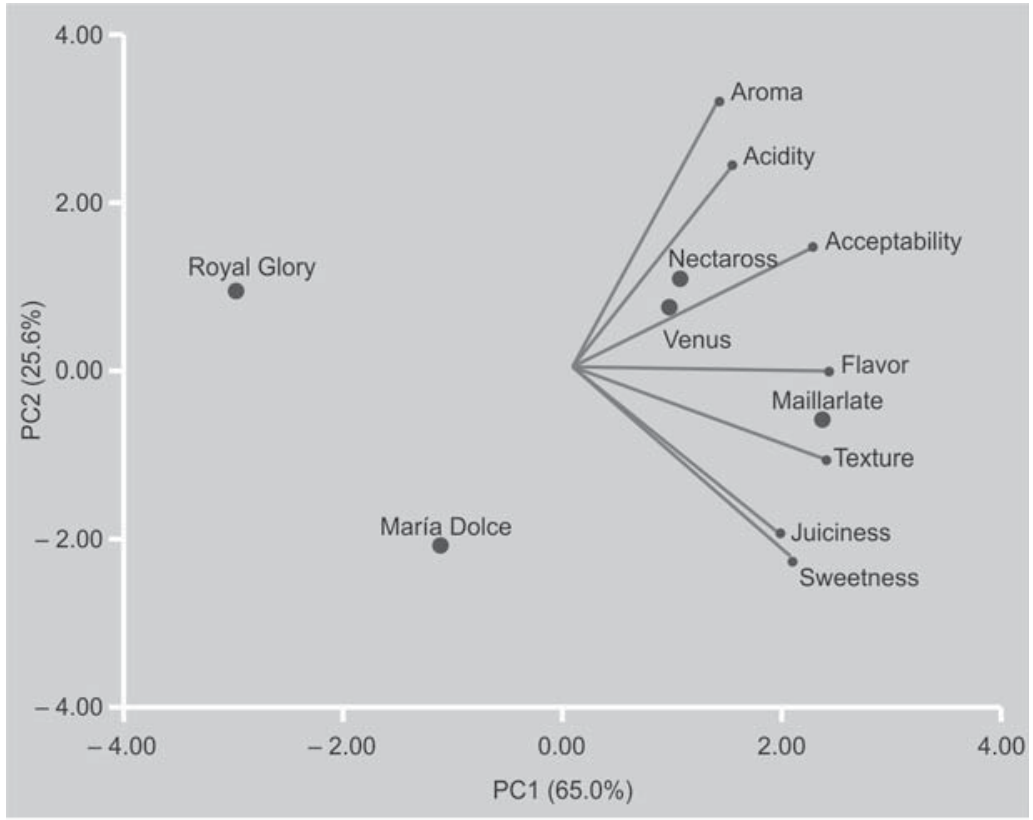

Figure 2.

Principal component analysis of sensory attributes of "treeripe" nectarine and peach cultivars determined through a trained panel (central Chile).

\subsection{Multiple linear regression}

A wide range of pre- and postharvest conditions can alter the synthesis and/or emanation of volatiles from harvested plant products that may be associated with flavor, ripening or other factors influencing quality or storage potential. To understand the aromatic profile of peaches, all those parameters that make it vary must be integrated, and one of the ways to achieve this is to use a multiple linear regression (MLR).

To generate the MLR, the attribute 'aroma' was determined using the trained panel as the dependent variable, while 'sweetness', 'acidity', 'juiciness', 'texture', 'flavor' and 'acceptability' were considered as regressor variable attributes. Furthermore, the electrical resistance signals, obtained from 56 sensors, were also considered as values for the regressor variables in the model. The regression model obtained is the following: $[$ Aroma $=-19.61+($ acidity $\times 0.28)+($ accept ability $\times 0.52)-($ sweetness $\times 0.33)+(\mathrm{S} 6 \times$ 23.36)].

The proposed model indicates that the attributes 'acidity', 'acceptability', 'sweetness' and the 56 resistance data are the main variables that define the aroma in the evaluated cultivars, presenting a mean square error (MSE) of 3.85 and a $R^{2}$ of 0.48 . When the model was used to make predictions on the 20 samples (four fruits per variety), the observed result of prediction was high $\left(R^{2}=0.89\right)$. The aroma-based MLR may prove the relative importance of each parameter when a sensory segregation of peach cultivars is required. According to Costell [41], the acceptability level of a food responds to a dynamic integration of all the stimuli produced by it, and there is an association among them. 'Aroma', one of the descriptors associated with acceptability, has been related previously to results obtained from e-noses, due to their capacity to segregate different cultivars. Other authors obtained positive correlations among the parameters 'flavor', 'sweetness' and 'aroma' and especially between 'aroma' and 'flavor' [42], which could suggest that consumers would be willing to pay more for more aromatic peaches with a better flavor [43]. In tomatoes, the separation of different genotypes in terms of their sensory quality

\section{Table II.}

Pearson correlation coefficients $\left(r^{2}\right)$ observed between attributes of sensory quality of "tree-ripe" nectarine and peach cultivars harvested in central Chile.

$\begin{array}{lccccccc}\text { Parameter } & \text { Acceptability } & \text { Aroma } & \text { Sweetness } & \text { Acidity } & \text { Juiciness } & \text { Texture } & \text { Flavor } \\ \text { Acceptability } & 1.00 & - & - & - & - & - & - \\ \text { Aroma } & 0.84 & 1.00 & - & - & - & - & - \\ \text { Sweetness } & 0.51 & -0,0028 & 1.00 & - & - & - & - \\ \text { Acidity } & 0.65 & 0.68 & 0.11 & 1.00 & - & - & - \\ \text { Juiciness } & 0.56 & 0.02 & 0.87 & 0.20 & 1.00 & - & - \\ \text { Texture } & 0.72 & 0.26 & 0.93 & 0.46 & 0.87 & 1.00 & - \\ \text { Flavor } & 0.84 & 0.53 & 0.83 & 0.50 & 0.65 & 0.91 & 1.00\end{array}$


was also achieved with an e-nose and a trained panel [8].

Through this work, it can be concluded that the e-nose is an instrument that measures a signal associated with the aroma perceived by the human nose in nectarines and might segregate different nectarine cultivars according to their sensory characteristics in a non-destructive way.

\section{Acknowledgments}

This work was supported by the research project 'Breeding Cling Peaches' of InnovaCORFO, VI Region, Chile.

\section{References}

[1] Shewfelt R.L., What is quality? Postharvest Biol. Technol. 15 (1999) 197-200.

[2] Infante R., Meneses P., Predieri S., Sensory quality performance of two nectarine flesh typologies exposed to distant market conditions, J. Food Qual. 31 (2008) 526-535.

[3] Predieri S., Missere D., Gatti E., Buona come una pera - Analisi sensoriale per scoprire vizi e virtù di un frutto, in: Ravaioli A., Mazzotti V. (Eds.), Pere dell'Emilia-Romagna IGP, Qualità tipica vera e protetta, 2001, pp. 114-117.

[4] Di Natale C., Macagnano A., Martinelli E., Proietti E., Paolesse R., Castellari L., D'amico A., Electronic nose based investigation of the sensorial properties of peaches and nectarines, Sens. Actuators B 77 (2001) 561-566.

[5] Sohn J.H., Smith R., Yoong E., Leis J, Galvin G., Quantification of odours from piggery effluent ponds using an electronic nose and a artificial neural network, Biosyst. Eng. 86 (2003) 399-410.

[6] Ayala-Zavala J.F., Wang S.Y., Wang C.Y, González-Aguilar G.A., Effect of storage temperaturas on antioxidant capacity and aroma compounds in strawberry fruits, Lebensm.-Wiss.Technol. 37 (2004) 687-695.

[7] Bonghi C., Ramina A., Ruperti B., Vidrih R., Tonutti $\mathrm{P}$., Peach fruit ripening and quality in relation to picking time, and hipoxic and high $\mathrm{CO}_{2}$ short-term postharvest treatments, Postharvest Biol. Technol. 16 (1999) 213222.

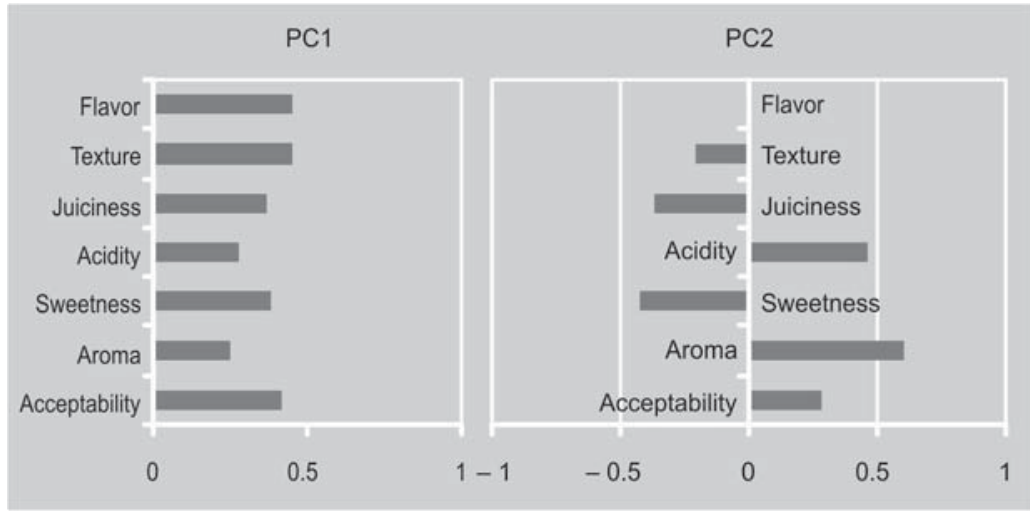

[8] Sinesio F., Di Natale C., Quaglia G., Bucarelli F., Moneta E., Macagnano A., Paolesse R., D'amico A., Use of electronic nose and trained sensory panel in the evaluation of tomato quality, J. Sci. Food Agric. 80 (2000) 63-71.

[9] Hernández Gómez A., Hu G., Wang J., García Pereira A., Evaluation of tomato maturity by electronic nose, Comput. Electron. Agric. 56 (2006) 44-52.

[10] Infante R., Farcuh M., Meneses C., Monitoring the sensorial quality and aroma through an electronic nose in peaches during cold storage, J. Sci. Food Agric. (2008) 20732078.

[11] Zhang H., Chang M., Wang J., Ye S., Evaluation of peach quality indices using an electronic nose by MLR, QPST and BP network, Sens. Actuators B 134 (2008) 332-338.

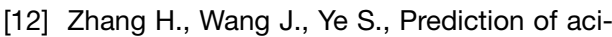
dity, soluble solids content and firmness of pear using electronic nose technique, J. Food Eng. 86 (2008) 370-378.

[13] McGuire R., Reporting for objective color measurements, HortScience 27 (1992) 1254-1255.

[14] Esposto S., Montedoro G., Selvaggini R., Riccò I., Taticchi A., Urbani S., Servili M., Monitoring of virgin olive oil volatile compounds evolution during olive malaxation by an array of metal oxide sensors, Food Chem. 113 (2009) 345-350.

[15] Di Rienzo J.A., Casanoves F., Balzarini M.G. González L., Tablada M., Robledo C.W., InfoStat versión 2008, Grupo InfoStat, FCA, Univ. Nac. Córdoba, Argentina, 2008.

[16] Balzarini M.G., González L., Tablada M., Casanoves F., Di Rienzo J.A, Robledo C.W., Manual del usuario, Editor. Brujas, Argentina, 2008, pp. 182-188.
Figure 3.

Pearson correlation coefficients of the sensorial descriptors of "tree-ripe" nectarine and peach cultivars harvested in central Chile, associated with principal components 1 (PC1) and 2 (PC2). 
[17] Pardo A., Ruiz M.A., SPSS11: Guía para el análisis de datos, Mc Graw Hill., Madrid, Spain, 2002, pp. 363-379.

[18] Crisosto C., How do we increase peach consumption? Acta Hortic. 592 (2002) 601605.

[19] Crisosto C., Crisosto G., Bowerman E., Understanding consumer acceptance of peach, nectarine, and plum cultivars, Acta Hortic. 604 (2003)115-119.

[20] Crisosto C., Crisosto G., Echeverría G., Puy J., Segregation of peach and nectarine [Prunus persica (L.) Batsch] cultivars according to their organoleptic characteristics, Postharvest Biol. Technol. 39 (2006) 10-18.

[21] Moriguchi T., Ishizawa Y., Sanada T., Differences in sugar composition in Prunus persica fruit and the classification by the principal component analysis, J. Jpn. Soc. Hortic. Sci. 59 (1990) 307-312.

[22] Robertson J.A., Horvat R.J., Lyon B.G., Meredith F.I., Senter S.D., Okie W.R., Comparison of quality characteristics of selected yellow- and white-fleshed peach cultivars, J. Food Sci. 55 (1990) 1308-1311.

[23] Fillon L., Kilcast D., Consumer perception of crispness and crunchiness in fruits and vegetables, Food Qual. Pref. 13 (2002) 23-29.

[24] Neri F., Pratella G.C., Brigati S., Gli indici di maturazione per ottimizzare la qualità organolettica della fruta, Frutticoltura 5 (2003) 20-29.

[25] Testoni A., Grassi B., Grassi M., Lovati F., Evoluzione della maturazione in pesche e nettarine in funzione della durata e del metodo di conservazione, Atti III Giornate SOI, 10-14 March 1996, Erice, Italy, 1996, pp. 369-370.

[26] Bellini E., Peach genetic improvement: "María Dolce", new nectarine with organoleptic value, Acta Hortic. 374 (1996) 39-41.

[27] Crisosto C., Crisosto G., Relationship between ripe soluble solids concentration (RSSC) and consumer acceptance of high and low acid meeting flesh peach and nectarine [Prunus persica (L.) Batsch] cultivars, Postharvest Biol. Technol. 38 (2005) 239246.

[28] Moreau-Rio M., Scandella D., Vénien S., Pêches et nectarines. Image et perception de la qualité, analyse sensorielle, Infos-Ctifl 108 (1995)12-17.
[29] Benedetti S., Buratti S., Spinardi A., Mannino S., Mignani I., Electronic nose as a non-destructive tool to characterise peach cultivars and to monitor their ripening stage during shelf-life, Postharvest Biol. Technol. 47 (2008) 181-188.

[30] Visai C., Vanoli M., Volatile compound production during growth and ripening of peaches and nectarines, Scientia Hortic. 70 (1997) 15-24.

[31] Saevels S., Lammertyn J., Berna A., Veraverbeke E., Di Natale C., Nicolai B., Electronic nose as a non-destructive tool to evaluate the optimal harvest date of apples, Postharvest Biol. Technol. 30 (2003) 3-14.

[32] Cavicchi, L., Profilo qualitativo sensoriale di alcune cultuvar di albicocco, in: Albicocco: Indicazioni varietali e techniche di produczione, Cent. Ric. Prod. Veg. (CRPV) 59, 2000, pp. 55-61.

[33] Moltó E., Selfa E., Ferriz J., Conesa E., Gutierrez A., An aroma sensor for assessing peach quality, J. Agric. Eng. Res. 72 (1999) 311-316.

[34] Di Natale C., Zude-Sasse M., Macagnano A., Paolesse R., Herold B., D'Amico A., Outer product analysis of electronic nose and visible spectra: Application to the measurement of peach fruit characteristics, Anal. Chim. Acta 459 (2002)107-117.

[35] Infante R., Gonzalez J., Early maturing peach embryo rescue and in vitro survival at different fruit growth stages, Acta Hortic. 592 (2002) 89-92.

[36] Hernández Gómez A., Wang J., Hu G, Gracía Pereira A., Discrimination of storage shelflife for mandarin by electronic nose technique, Food Sci. Technol. 40 (2007) 681689.

[37] Azondalou R., Darbellay C., Luisier J., Villettaz J., Amadò R., Development of a model for quality assessment of tomatoes an apricots, Swiss Soc. Food Sci. Technol. 36 (2003) 223-233.

[38] Parpinello G.P., Fabbri A., Domenichelli S., Mesisca V., Cavicchi L., Versari A., Discrimination of apricot cultivar by gas multisensor array using an artificial neural network, Biosyst. Eng. 97 (2007) 371-378.

[39] Plutowska B., Wardencki W., Aromagramsaromatic profiles in the appreciation of food quality, Food Chem. 101 (2007) 845-872. 
[40] Brovelli E.A., Brecht J.K., Sherman W.B., Sims C.A., Harrison J.M., Sensory and compositional attributes of melting- and nonmelting-flesh peaches for the fresh market, J. Sci. Food Agric. 79 (1999) 707-712.

[41] Costell E., Expectativas del consumidor desde el punto de vista sensorial, Alimentos 13 (1988) 63-67.
[42] Giacalone G., Peano C., lacona T., lacona C., Consumer testing on local and new cultivars of peach in the Roero area, Piedmont, Italy, Acta Hortic. 713 (2006) 457-460.

[43] Jordan J., Shewfelt R., Garner J., Variyam J., Estimating the value of internal quality aspects to consumers, Acta Hortic. 259 (1990) 139-144.

\section{Segregación de madura nectarinas para evaluación de la calidad sensoriale y con nariz electrónica.}

Resumen - Introducción. El objetivo de este estudio fue determinar la capacidad de una nariz electrónica para predecir la calidad de cuatro cultivares de melocotones y cuatro de nectarinas, en particular el aroma detectado sensorialmente por un panel de jueces entrenados. Material y métodos. La fruta se cosechó madura $(15 \pm 6 \mathrm{~N}$ de firmeza de pulpa) y las evaluaciones de calidad se realizaron un día después de la cosecha. Se describió la intensidad de los principales descriptores de la calidad de la fruta y luego se sometieron a una evaluación con una nariz electrónica. Se realizó un análisis de componentes principales (ACP) con los parámetros evaluados. Se realizó también una regresión lineal múltiple (RLM) para crear un modelo predictivo para el atributo "aroma" en comparación con el resto de los parámetros sensoriales más el sensor de la nariz electrónica que arrojó mayor información. Resultados y discusión. 'Royal Glory' y 'María Dolce' se agruparon en un grupo distante de 'Venus', 'Nectaross' y 'Maillarlate'. En el modelo de la RLM se incluyeron los atributos sensoriales 'acidez', 'dulzura' y 'aceptabilidad' y los datos del sensor 6 compuesto por SnO2, siendo éstos los factores que presentaron una mejor correlación con la variable "aroma", alcanzando un $R^{2}$ de 0,48 y un error cuadrático medio de 3,85. Se concluyó que la nariz electrónica es un instrumento capaz de discriminar entre variedades de melocotón a través de sus características aromáticas, las que determinan principalmente la aceptabilidad de la fruta.

Chile / Prunus persica / frutas / variedades / segregación / compuesto volátil / olfacción / instrumentos de medición 